** NB. This document is the accepted manuscript for Journal of Contemporary Painting, prior to proofing and copyediting, and without illustrations **

\title{
Painting as Commitment
}

Sunil Manghani

\begin{abstract}
Jean-Paul Sartre opens What is Literature? with the comment: 'No, we do not want to "commit" painting, sculpture, and music "too", or at least not in the same way. And why would we want to?'. Sartre's idea of the committed writer was a dominant and evocative account of intellectuals of the Left in the immediate post-war period, but was superseded with the arrival of 'theory' from Althusser onwards; and with post-structuralist notions fully decentering the subject. What might this mean for the painter? Taking an existential account of painting as its starting point, the article offers a reappraisal of the anti-aesthetic and postmodern debates of the 1980s, and suggests the need to re-situate painting as commitment in itself. Rather than simply the need to place painting within wider social networks, it is the inherent appeal to freedom that remains significant about the medium.
\end{abstract}

Keywords: anti-aesthetic, commitment, existentialism, network, painting, Jean-Paul Sartre

Sunil Manghani is Reader in Critical and Cultural Theory and Director of Doctoral Research at the Winchester School of Art, University of Southampton. He is an associate editor for Theory Culture \& Society and an editorial board member for the Journal of Contemporary Painting. He is the author of Image Studies: Theory and Practice (Routledge, 2013); Image Critique \& the Fall of the Berlin Wall (Intellect, 2008), co-author of Barthes / Burgin (EUP, 2016); editor of the fourvolume anthology Images: Critical and Primary Sources (Bloomsbury, 2013); and co-editor of Images: A Reader (Sage, 2006), an anthology of writings on the image from Plato to the present; and Painting: Critical and Primary Sources (Bloomsbury, 2015). He is also co-editor of Farewell to Visual Studies? (Penn State University Press, 2015), which is the final volume in the Stone Summer Theory Institute series, produced by School of the Art Institute of Chicago. 


\title{
Painting as Commitment
}

\author{
Sunil Manghani
}

And that masterpiece, 'The Massacre of Guernica', does anyone think that it won over a single heart to the Spanish cause? And yet something is said that can never quite be heard and that would take an infinity of words to express. (Sartre, 2001: 4)

At the start of Jean-Paul Sartre's (2001: 1) What is Literature?, he opens with the comment: 'No, we do not want to "commit" painting, sculpture, and music "too", or at least not in the same way. And why would we want to?'. Sartre's idea of the committed writer was a dominant and evocative account of intellectuals of the Left in the immediate post-war period. Underlying Sartre's existential philosophy is the idea that existence precedes essence; that we are not defined by something prior to ourselves, but that we are continuously defined by our own actions. We legislate ourselves and as such freedom is inherent to the human condition. To 'commit' is to be fully accountable to one's situation, and whereby we make choices and act. His account is superseded with the arrival of 'theory' from Althusser onwards; and with poststructuralist notions fully decentering the subject. Nonetheless, with the advent of new narratives of protest, social networks and community-engagement, the 'social' and 'political' in art have gained renewed currency. It is pertinent, then, to question what this means for the painter; i.e. what now we might come to understand as the 'commitment' of/to painting, as an aesthetic and/or ethical/political practice. In the postwar period, we can understand Sartre's desire for a progressive politics to come through (and even be sanctioned by) artistic practice. While today, within a postmodern context, it is more difficult to uphold any singular notion of progress (Gräbner, 2007). This article does not seek to argue the case for Sartre as such, indeed in his biography Sartre himself laments a certain failure of his profession. As he puts it: 'I took my pen for a sword; I now know we're powerless'. Yet he equally notes of the need to persevere: 'I write and will keep writing books; they're needed; all the same, they do serve some purpose. Culture doesn't save anything or anyone, it doesn't justify. But it's a product of man: he projects himself into it, he recognizes himself in it; that critical mirror alone offers him his image.' (Sartre, 1964: 253-254). It is perhaps just such a critical mirror that this article seeks to hold up, so offering a point of departure or critical prompt for reassessing more recent 
debates around painting. The opening two sections of this article provide a critical account of Sartre's views on commitment vis-à-vis art. This account is drawn through the lens of critical theory, notably French 'theory', which in turn contributes to Anglo-American post-structural and postmodern art criticism that turned against painting in the 1980s. The article re-examines debates around the anti-aesthetic and neo-expressionist painting; all of which is brought up to date in the closing section that places painting precariously within the context of new social networks. However, despite how we might 'place' painting, the underlying argument is that painting's inherent appeal to freedom is what remains significant about the medium.

Bridging Sartre with later post-structuralist thinkers (and the art theorists who draw upon them) might initially seem problematic. As Fox (2003: 1-9) notes, this is because Sartre's humanism has traditionally been pitted against the decentred subject. This article, however, takes its cue from accounts of a 'new Sartre' (Howells, 1992; Fox, 2003). Understood as a transitional figure of the modern to the postmodern condition, the main tenets of his philosophy can be argued to pre-figure many of the post-structuralist themes (e.g. the decentred subject is prefigured by the existential not essential individual). Thus, Hélène Cixous here comes to stand as an unlikely ally - particularly (at the close of the article) for the immediacy she recounts when situated before a painting. She writes, for example, '[t]he individual that I am is in a state of response to painting' (Cixous, 2012: 7); an evocation of a 'response' (responsibility?) that begins to connect with Sartre's views on commitment (here we might usefully keep in play John Cage's (1957: 10) rewriting of the 'responsibility' as 'response ability', subtly combing an ethics with an aesthetics). Of course, unlike Sartre, Cixous affords a greater degree of movement between painting and writing. " $\mathrm{A}] \mathrm{t}$ the moment when I say "I do not paint"', she writes, 'I say something which is true but which I could also alter by saying that if I paint, I do so otherwise' (2012: 7). Nonetheless, Cixous alerts us to 'artistic strife', a commitment inherent to all artistic practices, not least painting:

I know it by hearsay, one is at pains to create artistically, especially in painting. We have numerous evidence of the pain felt by painters. Of their ways of being at pains, of painting painstakingly [à la peinture et à la peine]. There are extremely notorious examples, the most notorious at pains in painting being probably Van Gogh ... But I think that this kind of combat in the throes of painting [qui font peineture] is a feature of painting. (2012: 7) 
As an epigraph to her essay, Cixous (2012: 7) writes: 'There is no art which is not an act of sublimated resistance'. We might read this critically to suggest of a neat, reified resistance. A convenient resistance. Packaged. Aestheticized (the aesthetic/anti-aesthetic problematic moves in and out of this query over a 'sublimated resistance'). In a commentary on committed art, Adorno (1974) is sympathetic to Sartre's position, but argues the move to emancipate is frequently a move to persuade, to construct another illusion. Autonomous works of art, he argues, function differently: 'By dismantling appearance, they explode from within the art which committed proclamation subjugates from without, and hence only in appearance. The inescapability of their work compels the change of attitude which committed works merely demand' (1974: 86-87). While the committed work might be said to make a prescribed demand (which can easily become predictable), the autonomous work is a 'demand' of its own being or doing. As will become apparent, despite very different attitudes towards the art of the day, Sartre and Adorno's views are perhaps in greater accord than we might think. From an existentialist perspective, artworks are not so much acts of resistance, but the making and remaking of the fact we are (or ought to be) free to receive the work; also, that the artwork is a social act. The first might be too general a remark to be useful, but the second is a condition we cannot ignore.

\section{Commitment as Model}

The writer is, par excellence, a mediator and his commitment is to mediation. (Sartre, 2001: 57)

In What is Literature? (2001) Sartre offers a concise, if cryptic, definition of commitment, yet there are various difficulties in adopting the notion for painting. Sartre, himself, is at pains not to draw parallels to literature. '[I]t is one thing to work with colour and sound,' he writes, 'and another to express oneself by means of words' (2001: 2). Yet, Sartre does makes repeated reference to painting (and music) in the course of the book and - albeit reading against the grain - it is possible to draw out a parallel, existentialist account of painting as commitment. It must be acknowledged, Sartre alters his position across a number of his texts. In What is Literature? he also presents a somewhat naïve account of the visual arts (making fairly bald references to canonical artists). Yet later essays collected in Portraits (Sartre, 2009) offer more nuanced accounts of painters, including Goya, Giacometti, Lapoujade, Masson and Wols. However, 
before speaking up for the painter in Sartre it is necessary to respond to a specific critique.

Yve-Alain Bois' (1990) thesis of 'painting as model' is in the main a reading, or a translation even, of Hubert Damisch's (1984) Fenêtre jaune cadmium, ou les dessous de la peinture; which includes a direct critique of Sartre's account of painting from his early text L'Imaginaire (1940), which appears almost a decade before What is Literature?. Bois suggests a key target for Damisch is the 'typically French genre, inaugurated on the one hand by Baudelaire and on the other presumably by Sartre, of the text about art by a literary writer or philosopher, each doing his little number' (Bois, 1990: 246). What Damisch supposedly reveals as erroneous is the 'stifling concept of image upon which the relation of this kind of text to art is founded - arrogant, ignorant, predatory texts that consider painting a collection of images to be tracked down, illustrations to be captioned' (Bois, 1990: 246). The reference here to 'image' is important. It raises a question about where or how one 'locates' the artwork. It is suggestive of a virtual quality (or reality) that is the work of art. There is a Cartesian split at stake, between the image (mind) and the painting (body), as the thing itself, the surface rendering.

Damisch's critique of Sartre revolves around the argument in L'Imaginaire that rather than consider 'aesthetic perception' we need to understand the aesthetic object as 'unreal' (or virtual), which Sartre refers to as the 'imaging consciousness'. Thus, as Damisch explains, for Sartre 'a portrait, a landscape, a form only allows itself to be recognized in painting insofar as we cease to view the painting for what it is, materially speaking, and insofar as consciousness steps back in relation to reality to produce as an image the object represented' (Damisch in Bois, 1990: 247). A clear difference of understanding would appear to emerge. Sartre is apparently only concerned with how we might 'read' a painting, whereas Damisch is concerned with it 'materially speaking'. Inevitably both writers can be situated in relation to the dominant artworks of their time. The account of Sartre here makes some sense in relation to mimetic and representational art, whereas Damisch is in correspondence with the work of abstract painters. Sartre's apparent blindness (or 'imaging attitude' as Bois puts it) to the materiality of the painting is not a problem specific to Sartre. As Bois explains, Damisch's view is that Sartre's position is simply a precursor to a wider problem with how art historians relate to the artwork. By contrast, Damisch's interest lies 'in the detail of the signifier,' not the signified, 'the texture of the painting, everything that, according to Sartre, insofar as it is real, "does not become the object of aesthetic appreciation”" (Damisch in Bois, 1990: 247). 
Damisch's key example is Mondrian, whose work he considers as a form of 'operation', a form of questioning and thinking in visual terms. Against the Sartrean 'imagining consciousness' that would seek to define full and empty space between the lines, Mondrian's painting precisely counters 'such impulses', hindering their movement 'whereby an unreal object is constituted from the tangible reality of painting, the eye being ceaselessly led back to the painting's constituent elements, line color, design' (Damisch in Bois, 1990: 248). Damisch explains how art is more 'difficult'; or rather how the painter (and viewer) can be led to think through painting. Sartre is said to align 'sensorial pleasure' with representational meaning in a painting, while conversely, for Damisch, painting is of no assignable end. As Bois explains (drawing on citations from Damisch):

Damisch's thesis is rigorously anti-Sartrean: in opposition to the 'imaging consciousness,' which necessarily has as its purpose the constitution of an image, he sees in Mondrian's canvases, in Pollock's, in Picasso's Portrait of Vollard, each with its own modality, 'an ever-reversed kaleidoscope that offers to aesthetic perception a task both novel and without assignable end ... the "meaning" of the work consisting precisely in this swarming and ambiguous appeal' [...]. Or again: 'If the painter has chosen to prohibit the imaging consciousness from giving itself free rein ... it is for the purpose of awakening in the spectator the uneasiness with which the perception of a painting should be accompanied' [...]. Now, this task of the painter is the stake of his art; it is what makes his canvas a specific theoretical model, the development of a thought whose properly pictorial aspect cannot be circumvented' (Bois, 1990: 248).

There is a precision to the writing of both Damisch and Bois that is quite different to that of Sartre. Their writing, however, is in the service of a narrower remit, specifically offering an account of modernist art. Bois outlines four 'models' in Damisch's account of the painting, which include the perceptive model (noted above), the technical model and the symbolic model. These are 'born directly from a confrontation with the works themselves'. A fourth model, however, the strategic, 'does not immediately take account of pictorial invention itself, of the status of the theoretical in painting, but of the conditions of appearance, of what establishes itself between the works' (Bois, 1990: 255). The strategic model takes up a 'metacritical position' and is is explained through the metaphor of chess; in particular the difference between the moves one might play within a match and the overriding rules of the game. Match/game is a variation on the structuralist formulation of parole/langue. Breaking 
with a historicist account of painting, it becomes possible to understand the development of painting as a match (between artists and styles) and as a game, as the possibility of painting. For Bois, the 'strategic approach has the advantage of deciphering the pictorial field as an antagonistic field where nothing is ever terminated, decided once and for all' (256).

The strategic model of painting refers to something explicitly outside of painting itself. It becomes situated within the world, evoking some kind of commitment (or at least structural relationship) to what stands outside of painting. Furthermore, the painter is attributed with generating a certain lucidity that is different to writing, but which conjoin. Against Sartre's humanist and essentialist account, Damisch and Bois present a (post)structuralist account, which upholds what is distinctive of the medium of painting, yet allows for its replication through a 'system' of meaning, or the 'game' of painting. Here the strucuturalist account (based upon structural linguistics) helps resolve a theory/practice divide, and enables art practice to emerge as 'research'. Yet, despite obvious differences, Bois' 'strategic model' is perhaps not so distant from Sartre's committed literature. Both are concerned with being situated within a wider frame. For Damisch painting is not simply about itself, but of problems that are not primarily problems of painting. Not match, but the game. In evoking Sartre's statement on the committed writer, as one who 'tries to achieve the most lucid and the most complete consciousness of being embarked' (2001: 57), it is worth noting the use of the word 'embarked'. To embark is both to begin and to register a sense of place. It is to accept a stepping out from one's self and surroundings: to be conscious of one's situation, and - as will be considered below - the inherent freedom to make choices therein.

\section{The Artwork: For and By Others}

Damisch's critique of Sartre's account of painting - that it is not about painting, but what painting shows - does not hold up so well when turning to What is Literature? It is certainly the case Sartre privileges the writer over the artist. The suggestion made is that in order to comment upon social issues, it is first necessary to translate or represent these issues. We require both a means to speak (parole or match) and a means to be heard (langue or game). And it is verbal (and literary) language for Sartre that is the most direct means of such mediation. He describes language as a form of prosthesis, through which we experience and communicate about the world. Yet here we can note that one of the reasons why he does not wish to 
'commit' painting as he might literature is that the former is not a collection of signs or symbols, but is itself a thing; so seemingly at odds with Damisch's criticism of Sartre. In fact, in What is Literature? Sartre describes painting in the following terms:

Tintoretto did not choose that yellow rift in the sky above Golgatha to signify anguish or to provoke it. It is anguish and yellow sky at the same time. Not sky of anguish or anguished sky; it is an anguish become thing, an anguish which has turned into yellow rift of sky, and which thereby is submerged and impasted by the qualities peculiar to things, by their impermeability, their extension, their blind permanence, their externality, and that infinity of relations which they maintain with other things. (Sartre, 2001: 3).

The writer can guide you and, if he describes a hovel, make it seem the symbol of social injustice and provoke your indignation. The painter is mute. He presents you with $a$ hovel, that's all. You are free to see in it what you like. That attic window will never be the symbol of misery; for that, it would have to be a sign, whereas it is a thing. The bad painter looks for the type. He paints the Arab, the Child, the Woman; the good one knows that neither the Arab nor the proletarian exists either in reality or on his canvas. (Sartre, 2001: 4).

It is clear, Sartre's frames of reference are very different to that of Damisch and Bois. And there are likely numerous criticisms that can be leveled at Sartre's reading of the painting. Even the dichotomy between writing and painting needs challenging. The good writer, for example, will equally seek to avoid 'types', and literature itself offers a phenomenology of discrete things, rather than a collection of symbols. The point to hold onto, however, is that Sartre's account here is far less focused upon what painting shows, than on a fuller experience. This is further evidenced in his essay of 1961 on Lapoujade (Sartre, 2009: 540-574). Turning his attention specifically to the abstract painter, who 'wants a concrete presence in every picture' (551), Sartre is at pains to avoid confusion: 'a meaning', he writes, 'is not a sign or a symbol or even an image' (552). The view of art expressed in this essay is beyond language, yet is not at odds with the idea of the committed artist as 'mediator' and effective communicator. As he puts it:

...it isn't true either that we communicate only by signs. We experience through others what others experience as we do; we are, for our fellow creatures, a shared source of 
experience. And these painters aspire precisely to impart the unity of their emotions an impulse or a release - to the canvas; in short, they choose the exhibition-going public as the people to whom to impart the experience of their own particular adventure. (Sartre, 2009: 562).

Sartre's suggestion that the good painter avoids templates is also significant. His account of committed literature cannot be described simply as a form of political writing, but rather through more indirect communication the writer is meant to bring about the conditions upon which the political is available, or opened, for consideration and deliberation. Here Sartre would seem to accord with Adorno when he suggests 'it is to works of art that has fallen the burden of wordlessly asserting what is barred to politics' (Adorno, 1974: 89). We can conceive of the committed painter as offering sights/sites of thought (and in this regard we can again see the correspondence with Bois's term 'model', whereby painting's model is one of commitment, or political and social awareness/openness).

<INSERT FIGURE 1 > <CAPTION > Figure 1: Robert Lapoujade, L'Explosion, 1961, oil on canvas. 75 x $100 \mathrm{~cm}$. Galerie Pierre Domec (from Lapoujade, peintures sur le thème des émeutes: triptyque sur la torture, Hiroshima. [Exhibition catalologue], Paris: Galerie Pierre Domec, 1961). | 'It is, I believe, quite a noteworthy event that a painter has been able to give such visual pleasure by showing us, unvarnished, the shattering bereavement of our consciences' (Sartre, 2009: 574).

Crucially, what underpins Sartre's account of the artwork, and its political significance, is the appeal to freedom. In turning to question why we write - which for our purposes we can ask why we might paint - Sartre outlines his existentialist philosophy in terms of the human act of revealing:

...it is through human reality that 'there is' being [...] It is our presence in the world which multiplies relations. It is we who set up a relationship between this tree and that bit of sky. [...] But, if we know that we are directors of being, we also know that we are not its producers. If we turn away from this landscape, it will sink back into its dark permanence. At least, it will sink back; there is no one mad enough to think that it is going to be annihilated. It is we who shall be annihilated, and the earth will remain in its lethargy until another consciousness comes along to awaken it. Thus, to our inner 
certainty of being 'revealers' is added that of being inessential in relation to the thing revealed. (Sartre, 2001: 27-28).

In this account, artistic creation is directly related to our sense of bringing the world into being (and the fact that we do not last forever in that world). Seemingly, in the case of the artwork itself, not only are we its directors, but also its producers. Yet for its creator the artwork is what 'sinks back into its dark permanence', since the artist cannot look at their own work as a work. For the artist it is always incomplete. Unfinished. Tethered to further prompting. 'A novice painter', Sartre writes, 'asked his teacher, "When should I consider my painting finished? And the teacher answered, "When you can look at it in amazement and say to yourself "I'm the one who did that!'” (2001: 28). Sartre's point is that the painter can never know when the painting is finished, as such it can only ever be for someone else to look at. It is always committed to another: 'There is no art except for and by others' (31).

The artwork is viewed as 'gift' (implying intentional exchange) and also as an appeal. In both cases, Sartre draws attention to an inherent sense of freedom: 'the appearance of the work of art is a new event which cannot be explained by anterior data. And since this directed creation is an absolute beginning, it is therefore brought about by the freedom of the reader, and by what is purest in that freedom. Thus, the writer [and painter] appeals to the reader's freedom to collaborate in the production of his work' (34). Here Sartre leans towards a Kantian notion of the artwork, being categorically different to other non-art objects. He writes, for example, how a hammer can achieve certain ends (and which may aid our freedom), but it does not bring us face to face with freedom. By contrast, the artwork 'does not serve my freedom, it requires it'. Thus, unlike a tool, the artwork is not a means to an end. Instead, re-working Kant's phrase of a 'finality without end', Sartre wants to suggest the artwork is an end, an entity, but without finality. The artwork is eventful:

It presents itself as a task to be discharged; from the very beginning it places itself on the level of the categorical imperative. You are perfectly free to leave the book on the table. But if you open it, you assume responsibility for it. For freedom is not experienced by its enjoying its free subjective functioning, but in a creative act required by an imperative. [...] The work of art is a value because it is an appeal. (Sartre, 2001: $35)$. 
Sartre account is not about the 'theatricality' of an artwork. It is not about leading the viewer into a certain kind of exchange. Yet it does not deny the artwork as bearing affect. For Sartre the key underlying point is that the artwork requires our freedom rather than serves it. It is not the presentation of a specific gift, but rather it is precisely the structural exchange of gifting:

It matters little whether the aesthetic object is the product of 'realistic' art (or supposedly such) or 'formal' art. [...] Vermeer's realism is carried so far that at first sight it might be thought to be photographic. But if one considers the splendor of his texture, the pink and velvety glory of his little brick walls, the blue thickness of a branch of woodbine, the glazed darkness of his vestibules, the orange-coloured flesh of his faces, which are polished as the stone of holy-water basins, one suddenly feels, in the pleasure that he experiences, that the finality is not so much in the forms or colours as in his material imagination. It is the very substance and temper of the things which here give the forms their reason for being. With the realist we are perhaps closest to absolute creation, since it is in the very passiveness of the matter that we meet the unfathomable freedom on man. (Sartre, 2001: 41-42)

The logical extension of Sartre's account is that art cannot exist in the suppression of freedom. There cannot be 'gloomy' literature or painting, he suggests, since 'however dark may be the colours in which one paints the world, one paints it only so that free men may feel their freedom as they face it' (47). In other words - like love - you cannot force an appreciation of the artwork, as it is dependent upon your conjoining with it. Sartre account is of course explicitly political, suggesting only democracy can contain the artwork. This seems more difficult to accept, since it appears to be blind to symbolic resistance that artworks provide. Although, again, this is an appeal to a notion of freedom: 'Writing is a certain way of wanting freedom' Sartre suggests, 'once you have begun, you are committed' (49). Is painting, then, also a 'certain way of wanting freedom'? Sartre is pragmatic: art has its limits. Art is not enough in the fight for a specific cause etc., but it is significant as part of one's commitment to the fight. Inevitably, the question arises for the painter (and writer): 'committed to what?'. To answer this, we might necessarily move forward in time, to engage with the postmodern dilemma of painting.

\section{Aesthetic / Anti-Aesthetic}


In the wake of the Second World War, given the experiences of occupation and resistance, it is understandable Sartre believed in progressive political reform and as a writer felt committed, even obliged, to address the social issues of the day. Equally, however, it is important to remember Sartre's notion of freedom is existential, it is of the vertiginous unease we experience when we recognize ourselves, our condition, as ours and ours alone. Along the lines of Nietzsche's pronouncement that God is dead, we are 'free' to become who we are. It is an unbearable lightness of being. However, despite any such portent, a contemporary reading of Sartre must contend with the changing intellectual landscape, with a shift to 'theory' (notable with Bois), and importantly the shift from modernism to postmodernism. As the grand narratives breakdown it becomes increasingly difficult to account for what commitment means, or what and for whom it purports to 'represent'.

Accounts of art and commitment, and the contrast raised by Adorno between the politics of political art and autonomous art, resurface with the debates of the aesthetic and anti-aesthetic that developed from the 1970s, and particularly in the 1980s with Hal Foster's (1985) edited volume on the anti-aesthetic (and postmodern culture). Many of the authors in this volumeincluding Foster himself - were highly critical of painting, with the emergence of neoexpressionism regarded as being complicit with the art market. For Foster the term 'antiaesthetic' was by no means intended to negate art or representation, but rather stood for 'a critique which destructures the order of representations in order to reinscribe them' (1985: xiii). As with the earlier pop art movement, the anti-aesthetic marked a shift from production to reproduction, however, it also drew upon post-structuralist articulations. Roland Barthes' (1984: 155-164) 'From Work to Text' is a key source in helping to rethink and indeed convert the art object itself to text. Added to which, as declared 'practices of resistance', the artwork associated with the anti-aesthetic denied a privileged aesthetic realm, looking instead to a wider fabric of social and cultural forms. Jenny Holzer's work, which literally places text into the public sphere, is a notable example of artwork in this vein. Rhetoric from politics, advertising and popular culture are 'destructured' in her work, and re-inscribed into the relevant social and cultural contexts. ${ }^{1}$ It is easy enough to see why painting - still very much held within the privileged aesthetic confines of the art gallery - was viewed dimly by those associated with the anti-aesthetic.

Foster's (1985) volume on the anti-aesthetic continues to be widely read, particularly in North 
America and parts of Europe, 'where it is often proposed as a historical document, a moment in the history of reactions against Modernism' (Elkins, 2013: 1). ${ }^{2}$ There are, of course, inevitable objections to the distinction of the aesthetic and anti-aesthetic and, typically, it makes more sense to view contemporary artistic practices as 'a mixture of aesthetic and nonaesthetic interests' (Elkins, 2013: 2); with the names Deleuze, Rancière, Nancy, and Danto etc. frequently evoked in arguments that go beyond the aesthetic/anti-aesthetic divide. Nonetheless, tracking the debates surrounding the tensions between the aesthetic and antiaesthetic remains instructive in thinking about how painting relates to ideas of commitment.

In Fredric Jameson's (1991) assessment of postmodernism, Warhol's Diamond Dust Shoes (1980) is juxtaposed with Van Gogh's A Pair of Shoes (1886). Unlike the latter, Warhol's work is said to no longer speak to us (Jameson, 1991: 8); his portrayal of shoes emblematic of what Jameson called the 'waning of affect', a filtering out of feeling, emotion and crucially subjectivity (10). As he remarks, the 'death of the world of appearance becomes thematized in certain of Warhol's pieces, most notably the traffic accidents or the electric chair series' (9). Yet, Jameson's account relates to the advance of a (post-)structuralist thesis of the 'Text', which allows for a subtle reading of intertextual, exchangeable sets of surfaces. Warhol does not set in train the waning of affect. '[It] is not,' Jameson writes, 'a matter of content any longer, but of some more fundamental mutation both in the object world itself - now become a set of texts or simulacra - and in the disposition of the subject' (1991: 9). The waning of affect relates specifically to the poststructuralist critique of hermeneutics. There is no hidden depth (or truth) to recover. The dichotomies of essence/appearance, latent/manifest, authenticity/inauthenticity, and signifier/signified run adrift, and replaced by 'a conception of practices, discourses, and textual play' (12). Within such a view Sartre's appeal to freedom is quickly subsumed as yet another surface, another projection, or indeed simply critiqued as a misguided quest for the authentic (for which there is no source). Whereas Bois' account of the painting as model fits more readily as identifying discourses and/or practices of research and thinking.

What emerges through Jameson's critique of postmodernism is a tension between communication and expression. Edward Munch's The Scream (1893), for example, while canonical as modernist expression, by its own logic cannot be sustained. The Scream's 'scream' loses its authority within the postmodern, which does not recognize the so-called bourgeois ego, or monad (Jameson, 1991: 11-12; 14-15). The waning of affect supposedly signals the end 
of the psychopathologies of the ego (as we witness in Munch's painting, or even in Sartre's account of our taking on our freedom). Yet, it signals much more besides: 'the end, for example, of style, in the sense of the unique and the personal, the end of the distinctive individual brush stroke (as symbolized by the emergent primacy of mechanical reproduction)' (15). The argument, for Jameson, is not that the postmodern is 'utterly devoid of feeling, but rather such feelings ... are now free-floating and impersonal' (15-16). David Salle's paintings of the 1980s are a good example of the free-floating and the impersonal. Sometimes confused as a neo-expressionist, simply for his use of paint, Salle's work deliberately undermines selfexpression. Despite strong brushwork the imagery is in fact clinically composed, typically with a deliberately flattened the palette (Heartney, 2001: 32); the painting are of the order of reproduction rather than production, in effect re-drawing elements of popular culture, pornography, art history and kitsch. ${ }^{3}$ As Heartney explains, for example, in Satori Three Inches Within Your Heart (1988) 'a flat monochrome rendering nullifies the erotic potential of the central nude, while the yellow overlay distances us from any emotional impact that the social realist tableau at the top might have possessed in its original form. Only the cut melon has any real resonance, suggesting a displaced sexuality that can only be experienced through eroticized objects' (Heartney, 2001: 33).

<INSERT FIGURE 2> <CAPTION> Figure 2: David Salle, Satori Three Inches within Your Heart, 1988, Acrylic oil paint on 6 canvases on wood. 2142 x $2910 \mathrm{~mm}$.

Artists working in the mode of the anti-aesthetic draw upon strategies of reproduction, of text and simulation. As Godfrey (2009:72) explains, “"appropriation” became the buzzword of the late 1980s, and the writings of the French theoretician Jean Baudrillard, with [the] talk of simulation and spectacle, became obligatory reading'. Furthermore, through the theories of the text (with the writings of Roland Barthes and Umberto Eco) '[t]he very concept of the artistic genius had long been under attack from the left-wing and feminist writers. Artists, it was argued, were to be seen as image administrators, not as geniuses expressing a personal vision and bringing news things into the world. There was nothing new to make, only old things to be reprocessed' (Godfrey, 2009: 72-73). The reference here to 'image administrators' is evocative; and it is little surprise that anti-aesthetic works became eminently relevant to media studies courses as much as fine art programmes. These works act as frontispiece for a critical understanding of mediated society and commodification. Along with Salle's 'cool' paintings (echoing the cool postmodern critique of Baudrillard's writings), the appropriation of an 
existing 'economy' of imagery is epitomized with the works of Cindy Sherman, Sherry Levine and Richard Prince. The works of these artists are all perfect examples to slot into a classroom Powerpoint presentation. The problem, of course, is that they become the very aesthetic of what they seek to critique. A perverse outcome of these works is that the 'image administrators' came to be not just those adept at appropriating imagery within the context of art, but also those with the financial acumen to make imagery pay.

\section{Image Administrators}

While Lichenstein's early renderings of Disney characters appear to have remained legally uncontested, a very different climate of intellectual property and image rights emerged in the 1980s (though interestingly Lichenstein's Donald Duck Lost and Found from 1960 was not exhibited publicly until 1982). Numerous legal proceedings were set in train during this period, perhaps most notably in relation to Jeff Koons. David Salle too was sued for his use of a drawing by the cartoonists Mike Cockrill and Judge Hughes (which they themselves had copied from a photograph). The postmodern, pick and mix approach apparent in Salle's work, and many others, is arguably itself part and parcel of the new economy of the image. The rise of what Rosalind Krauss (1980) called the 'paraliterary', the idea that the great writers of the moment were not so much novelists or poets but critical theorists, allowed for the 'theoretical idea' to become cultural (and financial) capital. Furthermore, by converting the artwork into Text, and moving the work out to the very sites of contest itself (e.g. the billboard, the movie screen, the street) - a process that had begun with pop art - the anti-aesthetic provided tangible methods for mythological critique through and of contemporary media culture. Alfredo Jaar's messages to the public across the LED screens of Times Square, Hans Haacke's remodeling of an advertising campaign, or the Guerrilla Girls' pronouncements outside the art gallery are all important critical texts. Yet, they soon become the lingua franca of commodity culture, or at least the terrain of a circular contest between ads and adbusting. When Barthes (1984: 165-169) reflected back upon the idea of 'Myth Today' as requiring a new task, 'no longer simply to upend (or right) the mythical message ... but rather to change the object itself' (169), he was alerting to the very same dilemma of the anti-aesthetic. The deconstruction of the commodity and of the image is not able to 'change the object', but only convert it into an endless chain of its own signification. Despite the importance of Barthes to the anti-aesthetic critics, it might appear the very 'objecthood' he suggests we 'change' is undermined. Barthes' 
whole approach to the myth (and what perhaps has maintained the enigma of his work Mythologies) is a combined aesthetic/anti-aesthetic. He writes with myth.

Hal Foster is today more sanguine about the imbrication of the aesthetic and the anti-aesthetic, and admits to the original debates having 'totalized the aesthetic and reified it as a bad object' (in Elkins \& Montgomery, 2013: 27). As he puts it: 'we were critics, not philosophers, in a very contested field of discourses and politics (which might be hard to imagine now)' (27). The primary target of the anti-aesthetic group was the neo-liberalist agenda epitomized by the Reagan and Thatcher governments in the US and UK respectively. The politics of the time led to a heightened critique (Elkins \& Montgomery, 2013: 37). Arguably, from a Sartrean perspective, the anti-aesthetics critics were committed critics responding in 'good faith'. Foster and others had accused neo-expressionist painters such as Clemente, Kiefer, and Schnabel as being neo-conservatives, having failed to argue successfully against modernism (or to improve upon it) and judged to be complicit with the art market. A case can be made, however, that turns the idea of the 'image administrators' back upon itself. The artists associated with the anti-aesthetic offered a form of 'cognitive mapping' (to borrow Jameson's phrase), which in the end, rather than renew historical consciousness, itself becomes a consumerist language. This is not to suggest the anti-aesthetic was in anyway complicit with the market, but that it was not necessarily as 'destructuring' as it had initially hoped.

An example can be made with reference to the graphic editing software, Photoshop, which dates back to 1988 . Today this program is synonymous with image manipulation, and much associated with the 'cut 'n' paste' tool (something Richard Hamilton uses to great effect in his 1992 remake of the canonical Just what is it that makes today's homes so different?). Looking back at anti-aesthetic artworks of the 1980s it is possible to see a convergence of a similar set of desires and techniques of the postmodern image. Prince's depictions of the Marlboro Man are akin to neatly airbrushed imagery and Richter's paintings are now reflected in the combining of numerous image filters. While Robert Longo's Jules, Gretchen, Mark, State II (1982-3) reminds us of the contemporary uses of masking techniques (reminiscent, for example, of the iconic iPod advertising). And James Rosenquist's work, and even that of David Salle, suggest of a Photoshop-style layering and filtering of components to build flat, montaged pictures. It should not be forgetton, however, that a key metaphor underling much of the Photoshop interface is of course the paintbrush and the artist's palette. In using the various tools, it is soon apparent that actually 'painting' digitally is very difficult. It is difficult technically (physically), but also 
conceptually, or rather imaginatively. Painting rather than cutting (and pasting) the image presents a different phenomenological or existential form of engagement. Foster's criticism of neo-expressionism for its erosion in consumerist amnesia might actually be more appropriately considered in terms of anamnesia, not a loss then, so much as a form of recollecting (Lyotard, 2004).

Christopher Le Brun's dreamlike images illustrate this point. Figures emerge through abstraction, making his paintings a form of witness to a constant oscillation of image/material, figure/abstraction. To use Lyotard's formulation, Le Brun's work is of the mode of 'event'. In contrast to 'cognitive mapping', Lyotard's postmodern is argued less as a matter of retracing, repetition, but rather 'a procedure in "ana-": a procedure of analysis, anamnesis, anagogy and anamorphosis which elaborates an "initial forgetting”" (Lyotard, 1992: 93). Conceptually it is prior to the modern; the unwritten forms prior to the codifications of a modernist agenda. And writing specifically on painting, he argues it is 'a struggle, a labour in the strong sense of the word as it is used in obstetrics, Arbeit as Freud used the term in relation to overcoming resistance' (Lyotard, 2004: 107). Painting connects with the 'talking cure' of psychoanalysis, the painter 'has to labour to keep open the passage through which may come what has not yet come' ${ }^{4}$ To return to the terms used by Sartre, we can understand the painter as the producer of the work, yet not necessarily the director. Different to any attempt to 'upend' the sign (to write up History in as truthful a language as possible), Lyotard (2004: 108) frames his account of the painter around the concept anamnesis; a partial, fleeting and difficult form of recollection. Christopher Le Brun's work connects well with such accounts. The recurring image of a white horse - which often only haunts the canvas - is not the form Le Brun is trying to paint, but as 'a matter of working to reach the disposition one already has' (Lyotard, 2004: 108) the process of painting cannot help but give life to this form. Thus, for Le Brun, the process is decidedly not about appropriation (see Le Brun in Godfrey, 2009: 85). In contrast to the cool, cynical and appropriationist works of the 1980s, neo-expressionist painting - at least potentially maintains an openness, a freedom (along the lines of Sartre's account) that is not depicted but required, both in its production and viewing. Understood this way, it is not so surprising that even today 'much painting currently in art schools and commercial galleries should still be categorized as neo-expressionist' (Godfrey, 2009: 61).

Claims of complicity with the market appear to have been somewhat shortsighted. Nonetheless, a more important persistent criticism of neo-expressionism concerns its wider significance. As 
Godfrey (2009: 68) notes, the historian Simon Schama has referred to the 'Kiefer syndrome', questioning whether the re-construction of myth can in fact be taken seriously. As Godfrey puts it: 'There is a thin line between the myths that a whole society believes in and shares, and mere personal fantasy, which can degenerate to private language or self-indulgence' (69). As a suggestion of how to stay on the right side of this thin line, Godfrey offers the example of the Swiss painter Helmut Federle:

Federle returns again and again to a few simple motifs. His Basics on Composition was a series that extended over several years, always the same size, always with the same limited shapes and range of colours. [...] Although the motifs are stark they are painted very freely, so that the surface is often complex, frequently reworked. [...] As for many other painters, working in series was a way to approach the subject or problem again and again and also to produce a body of work that was clearly interrelated and hence satisfying to see as a group. We must remember that the key unit in a painter's career is to some extent not the single painting but the room filled at exhibition with their works. (Godfrey, 2009: 86).

Painting in series is another important corollary of the painting as model, and of painting as commitment itself. The idea of working and reworking at the same problem in the studio, again and again, itself suggests of a significant commitment (if only a personal one). The ongoing dilemma (to evoke the so-called 'Kiefer syndrome') is of course whether or not the work (being what it is and the labour undertaken) can be taken to be meaningful for a wider constituency. The question is whether the 'project' of the painter (as a body of work) truly works its way out from the artist's studio. For which there are a number of wider consideration besides the painting itself.

\section{More Besides...}

At an event at Tate Britain on the painting 'as document' ${ }^{5}$, the artist Clare Woods spoke eloquently about her working processes. She adopts very particular strategies for collecting materials to direct the forms in her compositions. She engages in an almost sculptural approach, working typically with layers of enamels, both masking off areas and allowing various affordances of the paints as they interact. The painting she chose to discuss at the event was 
Francis Bacon's Study for a Portrait (1952). She was drawn to specific technical elements in the painting. She spoke, for example, about the difficulty of preparing and using the colour pink. For Woods this was certainly not an ideological problem (i.e. with the associations of pink), it was a technical and aesthetic problem for which Bacon offered some solutions. Woods referred frequently to her studio as the site of her practice. It is where she works. Her practice can very evidently be understood in terms of Bois' account of painting as model. Woods is working with and through a visual (and in part, sculptural) form of thinking and 'research'. One might question whether the works even need to be displayed (other than for professional and commercial purposes). At one point she remarked candidly ' ...the moment the painting leaves the studio my commitment to it is over. I move on to the next thing'. Clare Woods' public profile has of course grown, not least with the completion of her large-scale project for the Olympic Delivery Authority (in London, 2012). Two walls, totaling 125 meters, present dramatic mural paintings on the outer boundary of the Olympic Park in East London. The paintwork has in fact been transferred to many thousands of mosaic tiles (acknowledging that the original site was historically the location of a ceramic tile factory). With a commission such as this, it would be hard to believe the moment the painting leaves the studio the commitment to the work ends. Yet, equally the environment these works are placed into make it difficult to remain committed. Running along the top of the walls can be seen obligatory security fencing and CCTV cameras pepper the area. In effect, the function of these high, elaborately painted walls is to secure (and obscure) the massive electricity generators for the Olympic park. In places the artwork itself is punctuated with a standard yellow hazard warning sign: 'Danger of Death' (the international symbol showing a person knocked down by a zigzag arrow or bolt of electricity). The walls literally stand to shut people out from certain spaces, and arguably shut people out from the artwork itself. Indeed, the walls run close to set of service roads and a busy flyover, making it physically difficult to get any adequate viewpoint, and the painterly designs are largely lost to the semiotic clamour of street signs and structures. We might suggest there is an anti-aesthetic aesthetic underlying such commissions; in other words, a calculated, instrumentalist placement of art into society, which will always prove contentious (and reducing the artist to cultural laborour).

<INSERT FIGURE 3> <CAPTION > Figure 3: Clare Woods, Brick Fields and Carpenters Curve, Olympic Delivery Authority Art Commissions, London. Digitally printed ceramic tiles, 2012. Photograph: Sunil Manghani. 
The problem of placing painting into our lives has received increased attention, not least with David Joselit's (2009) article 'Painting Beside itself'. The article begins rather promisingly by raising the question of how painting might belong to a network. 'This late twentieth-century problem,' writes Joselit, 'whose relevance has only increased with the ubiquity of digital networks, joins a sequence of modernist questions' (2009: 125). It is no coincidence, for example, that in first researching the above-mentioned work by Clare Woods, the World Wide Web offered a ready store of pictures and words. Joselit relies upon a rather curious key example to develop his account of the network. It is a painting by Jutta Koether, Hot Rod (after Poussin), which is a near monochromatic reworking of Poussin's Landscape with Pyramus and Thisbe (1651) and is mounted on an angled floating wall, or screen, in the artist's exhibition Lux Interior (2009). In addition to the canvas itself (and its particular placement), there were also three lecture performances in accompaniment, in which 'Koether moved around and even under the wall that supported her canvas [...] The painting's own presence as a personage — or interlocutor - was further enhanced by strobe lights flashing onto it in different configurations during these live events as if painting and painter had encountered one another in a club' (Joselit, 2009: 127). Joselit argues the exhibition offered a 'sophisticated response' to the question of the network. He wants to acknowledge the sheer difficulty of visualising networks, which range 'from the impossibly small microchip to the impossibly vast global Internet' (128). Koether's approach, he argues, manages to come to the problem in a different way: 'Instead of attempting to visualize the overall contours of a network, she actualizes the behavior of objects within networks by demonstrating what I would like to call their transitivity. The Oxford English Dictionary gives one definition of "transitive" as "expressing an action which passes over to an object"' (Joselit, 2009: 128). Such theorization of the transitive is perhaps plausible in the abstract, yet, in combination with the description of the actual work of art, Hot Rod would seem to be more performance than networked. The fact that a particular lamp has been salvaged from a famous nightclub and that the paintwork has a blood like quality lends itself to certain (textual) themes but hardly a network - at least not the networks of distribution and exhibition that are initially evoked by the article. Also Koether's moving around and underneath the work through the performance pieces does not reveal networks and certainly does not help us to imagine the painting as an interlocutor, let alone a 'personage'. There is something altogether too convenient about Joselit's account which undermines an interesting proposition of the transitive artwork. We might suggest 'Painting Beside Itself' is an example of a contemporary phenomenon, the waning of theory, or a collapse of an established form of critical theory still wedded to an aesthetic space that simultaneously is declared illusionary (and 
exclusionary).

The fact that Hot Rod is bolted into both ceiling and floor by unbending metal rods, tethering the painting to the gallery space, is revealing of a presumption made when asking how the painting belongs to the network. Aside from the obvious ideological (and quite hermetic) construct of the art world that maintains a specific set of largely commercial networks (i.e. artists, agents, galleries, visitors etc), painting is perhaps not so transitive after all. Rather, painting is stuck or moored in the 'network'. With regards to digital networks, there is a surfeit of images of paintings on the internet, but these do not provide us the means to see painting. It rarely affords, for example, sufficient opportunity to comprehend painting as 'a body of work' or a practice (as noted above with regards Federle's work), and more fundamentally of course we do not get to experience painting's materiality. Thus, Koether's ducking and diving beneath her canvas might be viewed more critically as less a commentary on the painting in the network than a mistaken attempt to stitch (a) painting into the network in the first place.

Joselit's theory of the transitive painting arguably remains the purview of a fairly limited audience who are already 'committed' to such thinking. In a commentary in Beyond the Aesthetic and Anti-aesthetic (Elkins and Montgomery, 2013), Luis Camnitzer (2013) raises a related concern for the dialogues held around theoretical arguments of the anti-aesthetic. 'The possible shortcomings of these sorts of exchanges' he writes, 'are that the people involved in them are the only public addressed, and in their earnestness, while advancing a good and important intellectual depth, they have the side effect of fostering bad social stratification' (Camnitzer, 2013: 195). His concern is not simply about the politics of such public engagement, but is directly related to our aesthetic engagement with art. 'The many excluded publics', he writes, 'are by default reduced merely to looking (if they look at all) at the outer shell of the art object. They're left with little to work with except their own (schematic) taste and handed down dicta, reaching in the end a useless “consumer” opinion' (195). By contrast, Camnitzer 'problem solving' as the basis for making art, whether conscious or not. And here we can trace elements of Sartre's account of art as being for and by others. 'Once people get beyond conceiving of art as the appreciation of objects,' writes Camnitzer, 'they are able to join artists and theoreticians in the activity of making "illegal" connections, the kinds of connections that are possible when the constraints of disciplinary thinking are removed' (195-196). Perhaps we could argue that Koether's work does in fact adhere to such an approach. Certainly, the idea of 'illegal' 
connections (notably in inverted commas) seeks to attest to a belief in the imaginative act of painting, which for Sartre lies at the heart of the proposition that the artwork is an appeal to our freedom - that it does not serve freedom, but requires it.

When making an educational visit to a school in a violent neighbourhood in Caracas, a teacher remarks to Camnitzer: 'Why should we refer to your art examples ... if they were made without our population in mind?'. This might be expressed as the limits of commitment, which cannot transcend social and culture specificities. As Camnitzer explains, '[t]he question was not aggressive, and it didn't reflect a demand for "local" art or narratives of identity. The concern expressed was much more general. It was mostly about detachment, something like having to follow pointless or incomprehensible orders' (2013: 196). Like many educational contexts in the wake of the critical discourses of the 1970s, this school had adopted a fairly typical curricular model: 'Students were shown works of art and then were invited to discuss them. (what do you see? What makes you say that? And so on)' (196). A scene from John Berger's TV broadcast of Ways of Seeing (1972) illustrates this approach to great effect. A group of school children sit around Berger discussing a painting by Caravaggio. In their conversation the children lead - without direct prompting - to a nuanced consideration of (gendered) ambiguity in the painting. This idea of sharing in a non-hierarchical, but informed discussion can be said to have unpinned for decades now agendas around art access and engagement. But there is a problem with such an approach. We are led to react to (and 'read') painting, rather than, in the words of Cixous (2012: 8), 'holding forth in front of painting'. It is as if there is some luck to what happens in such moments. Cixous is very candid about her gap in knowledge about painting (or at least art history). Before the painting, she suggests, '[e]ither I hear nothing ... I remain apathetic, passionless, I am unimpassioned ... or, on the contrary, I am deeply moved, I am affected and of course I have absolutely no idea why' (2012: 8). Of course, it does not then follow that we must know why. Indeed, such an occasion allows Cixous to write:

This is when my thoughts start drifting towards writing. In front of such and such a painting, which touches me, I take notice of it, I re-mark the emotion. And I put it aside because I am on the side of jouissance [...] I am not a 'lover' of paintings or of any other art, for that matter. I am somebody who lends herself to experiences which are vital, decisive, coming from elsewhere [...] One receives a work, whichever it is, only if it speaks to us in a language which is at once ours and not ours. It is at once me and not me. (Cixous, 2012: 8-9) 
Unlike Joselit's account of Koether's work, which tethers what lies besides painting (a 'fixing' of jouissance), Cixous' account pertains to a more open engagement; one that appeals more readily to the demand made to Camnitzer ( 'Why should we refer to your art examples?'). Cixous has crafted her own refined strategies for handling the encounter she has with art's vital and decisive experiences. She is adept to move art in and out of different kinds of networks, including philosophical and critical discourses. In effect, she is 'problem-solving'. This is not to suggest some tangible, practical problem requiring an immediate fix, but a more fundamental, existential form of inquiry, which brings her into contact with, as she describes, 'the me I do not know'. The question, of course, is how the network as a network can foster and sustain such levels of engagement. It is important we get away from reacting as a 'consumer' of the artwork; to break with a rigid subject/object relationship that too readily leads us to simply being switched on or switched off by a painting.

In keeping with Cixous' remarks, there is a more fundamental question about how we might conceive networks within which painting is live (and even painful) to us. There are lots of ways in thinking about our commitment to painting, and painting as a form of commitment. Sartre's commitment, being part of an intellectual group to stake out political commitment within one's writing, or art, requires alertness to one's own situation. Such commitment can quickly become hollow, or even a form of privilege (indeed how do we even know how to grasp our times; and if we do, who are 'we' to do so?). Akin to the phrase 'to commit to paper', Sartre's commitment can quickly mark out differences, the same way we mark out the different shapes to form letters upon a page as to codify, to set meaning. Such mark making is to make cuts for and against. As Adorno (1974: 88) argues: 'Committed works all too readily credit themselves with every noble value, and then manipulate them at their ease. [...] The notion of a "message" in art, even when politically radical, already contains an accommodation to the world'. Conversely, we can be 'entered into', or 'committed', as we would say in being committed to an asylum. Commitment in this sense is almost to be taken hostage. Similarly, we might describe ourselves being committed to a role, a vocation; to be devout even. It is in this regard we might understand the impact of modernist art practices, which have led to the vocation of the painter as experimenter (Bann, 1970), or in pursuit of 'models' (Bois, 1990). Clare Woods, for example, may consider her commitment to the artwork to be over once it leaves her studio, yet she herself is unable to leave, committed to the space where she will continue to make work. 
<INSERT FIGURE 4> <CAPTION > Figure 4: Francisco Goya, The Dog, c. 1819-1823.

Oil mural on plaster transferred to canvas. $131.5 \mathrm{~cm} \times 79.3 \mathrm{~cm}$.

It is, then, the configuration of painting and network which raises the main challenge to both our social and philosophical relationship to this medium. Painting's immediate network is an insular one made for and by those initiated within it. A common indicator of one's commitment to this group is having seen painting at its source. 'Are you familiar with x artist?' you will be asked.' Have you seen their work?' If not, there is a dilemma in how the conversation can proceed. We have to consider how to negotiate the impossibility to share painting. Cixous, who would consider herself on the fringes of the discourse of painting, is equally bound by the question as to whether one has seen the painting. In talking of Goya's painting of a dog half buried in sand, she asks her interviewer: 'Do you know that painting? Have you seen it? It's incredible. It's vertical, and it's as if it were the epitome of all the spirit of painting [...] It is the most incredible picture you can see, and it's so nothing because it's really only infinites' (Cixous, 2008: 147). Our commitment to a painting (and our hope for that painting to offer commitment to others) can all too frequently rely upon the performative: 'it's incredible', 'beautiful, 'terrible'. This is often all we have at our disposal to place it into a network of signification and communication. In his essay on Cy Twombly, Barthes (1985: 191) refers to this as the 'subject of pleasure, the one who enjoys himself in front of the canvas,' yet is not good at expressing the experience (indeed it is at this moment he suggests language fails). Yet, as has been considered here, the true import such a painting can have upon a network is its appeal to our freedom (to be before it, to have the means to accept its appeal): The question it poses to us. As Cixous (2012: 11) notes of Goya's half buried dog: 'One does not know what this half burial is. Is it being buried completely? Is it being inhumed or exhumed? Is this dog fleeing for safety or being saved? The painting is a question'. It is a meta-painting. It is a painting about how we are placed in painting's appeal. And as Camnitzer's approach to painting might suggest, we must take seriously our custodianship to painting's question instead of simply the paintings themselves and their trailing discourse. Where Sartre reminds us of the artwork's inherent appeal to freedom, we might readily wish to extend in our present context to the more plural 'freedoms', but in short, we can remind ourselves of painting as existential: we formulate it, yet we are thrown out by its formulations. For some, Goya's Dog is exemplary: its only commitment is to the grip of life - though, indeed, that is some commitment to have. 


\section{References}

Adorno, Theodor, W. (1974) 'Commitment', trans. by Francis McDonagh, in New Left Review, Issue 87-88 (Sept-Dec.), pp.75-89.

Bann, Stephen (1970) Experimental Painting: Construction, Abstraction, Destruction, Reduction. London: Studio Vista.

Barthes, Roland (1984) Image Music Text, trans. by Stephen Heath. London: Fontana.

Barthes, Roland (1985) 'The Wisdom of Art' in The Responsibility of Forms, trans. by Richard Howard. New York: Hill and 'wang, pp. 177-194.

Bois, Yve-Alain (1990) Painting as Model. Cambridge, Mass.: MIT Press.

Cage, John (1957) Silence. Cambridge, MA: MIT Press.

Camnitzer, Luis (2013) 'Theory Cataracts' in James Elkins and Harper Montgomery (eds.) Beyond the Aesthetic and the Anti-Aesthetic. Pennsylvania: Pennsylvania State University Press, pp.195-197.

Cixous, Hélène (2008) White Ink: Interviews on Sex, Text and Politics, ed. By Susan Sellers. Stocksfield: Acumen

Cixous, Hélène (2012) Poetry in Painting: Writings on Contemporary Arts and Aesthetics. Edinburgh: Edinburgh University Press.

Damisch, Hubert (1984) Fenêtre jaune cadmium, ou les dessous de la peinture. Paris: Seuil.

Elkins, James (2013) 'Introduction' in James Elkins and Harper Montgomery (eds.) Beyond the Aesthetic and the Anti-Aesthetic. Pennsylvania: Pennsylvania State University Press, pp.1-16.

Elkins, James and Montgomery, Harper (eds.) (2013) Beyond the Aesthetic and the Anti-Aesthetic. 
Pennsylvania: Pennsylvania State University Press.

Foster, Hal (ed.) (1985) Postmodern Culture. London: Pluto Press.

Fox, Nik Farrell (2003) The New Sartre: Explorations in Postmodernism. New York: Continuum.

Godfrey, Tony (2009) Painting Today. London: Phaidon Press.

Gräbner, Cornelia (2007) 'Commitment' in Griselda Pollock (ed.) Conceptual Essays: Passages to Cultural Analysis. London: I.B. Tauris, pp.172-218.

Heartney, Eleanor (2001) Postmodernism. London: Tate Publishing.

Howells, Christina (ed.) (1992) The Cambridge Companion to Sartre. Cambridge: Cambridge University Press.

Jameson, Fredric (1991) Postmodernism, or, The Cultural Logic of Late Capitalism. London Verso.

Joselit, David (2009) 'Painting Beside Itself', October, No. 130, Fall 2009, pp. 125-134.

Krauss, Rosalind (1980) 'Poststructuralism and the "Paraliterary"', October, Vol. 13 (Summer), pp.36-40.

Lawson, Thomas (1985) 'Last Exit: Painting' in Richard Hertz (ed.) Theories of Contemporary Art. New Jersey: Prentice Hall, 1985, pp. 143-155.

Lyotard, Jean-François (1992) 'Note on the Meaning of "Post-“' in The Postmodern Explained to Children: Correspondence 1982-1985. London: Turnaround, pp.89-93.

Lyotard, Jean-François (2004) 'Anamnesis: Of the Visible', Theory, Culture \& Society, Vol. 21, No. 1, pp. 107-119.

Sartre, Jean-Paul (1940) L’Imaginaire. Paris: Éditions Gallimard. 
Sartre, Jean-Paul (1964) The Words, trans. by Bernard Frechtman. New York: George Braziller.

Sartre, Jean-Paul (2001) What is Literature?, trans. by Bernard Frechtman. London: Routledge.

Sartre, Jean-Paul (2009) Portraits (Situations IV), trans. by Chris Turner. London: Seagull Books.

\footnotetext{
${ }^{1}$ Hal Foster's account of the anti-aesthetic is sympathetic to Adorno's claims for the autonomous artwork as a form of critique. Yet, he considered such 'aesthetic space' to have lost its power, writing 'its criticality is now largely illusory (and so instrumental)' (Foster, 1985: xiii). Foster suggests instead 'the strategy of an Adorno, of "negative commitment", might have to be revised, or rejected, and a new strategy of interference (associated with Gramsci) devised' (xiv). The work of someone like Jenny Holzer can certainly be understood as a form of interference.

${ }^{2}$ As recently as 2011, the 'anti-aesthetic' was the focus of a week-long, international seminar as part of the Stone Summer Theory Institute, at the School of the Art Institute of Chicago, and subsequently published as Beyond the Aesthetic and Anti-aesthetic (Elkins and Montgomery, 2013).

${ }^{3}$ David Salle is a key example in Thomas Lawson's (1985) account, 'Last Exit: Painting', of an artist able to 'operate by stealth' at the heart of the market. In the case of Salle's works, then, Lawson argues approvingly: 'They are dead, inert representations of the impossibility of passion in a culture that has institutionalized self expression' (1985: 150).

${ }^{4}$ Lyotard refers here to the 'event' of painting: 'The eye is ready for the pictorial gesture, prepared for what cannot be anticipated: the event. This is not because the gesture would erupt unexpectedly. On the contrary, it would have been expected and ardently wished for. But it is an event in that the subject giving birth to it does not know, cannot analyse and does not control. (Lyotard, 2004: 107).

5 'Painting as a Document', Paint Club, at Tate Britain, 25 April 2014. < http://www.tate.org.uk/whatson/tate-britain/talks-and-lectures/paint-club-painting-document $>$ (Accessed on 24 April 2015). Further references to commentaries from this event are based on the author's notes taken at the time.
} 